\title{
Quantitative study of BAALC- and WT-expressing cell precursors in the patients with different cytogenetic and molecular AML variants treated with Gemtuzumab ozogamicin and hematopoietic stem cell transplantation
}

\begin{abstract}
Nikolay N. Mamaev, Alyona I. Shakirova, Tatiana L. Gindina, Sergey N. Bondarenko, Bella I. Ayubova, Ildar M. Barkhatov, Yana V. Gudozhnikova, Valentina M. Kravtsova, Mikhail M. Kanunnikov, Olesya V. Paina, Zhemal Z. Rakhmanova, Tatiana Yu. Gracheva, Ludmila S. Zubarovskaya

RM Gorbacheva Research Institute of Pediatric Oncology, Hematology and Transplantation, Pavlov University, St. Petersburg, Russia
\end{abstract}

Professor Nikolay N. Mamaev, RM Gorbacheva Research Institute of Pediatric Oncology, Hematology and Transplantation, Pavlov University, 12 Roentgen St, 197022,

St. Petersburg, Russia
Phone: +7 (911) 7605086

E-mail: nikmamev524@gmail.com

Citation: Mamaev NN, Shakirova AI, Gindina TL et al. Quantitative study of BAALC- and WT1-expressing cell precursors in the patients with different cytogenetic and molecular AML variants treated with Gemtuzumab ozogamicin and hematopoietic stem cell transplantation. Cell Ther Transplant 2021; 10(1): 55-62.

\section{Summary}

There is evidence that relapses of acute myeloid leukemia (AML) are closely related to heterogeneous population of leukemic precursors. At least, two classes of the leukemia-initiating cells (LIC) may be discerned, according to recent experimental studies with hematopoietic cell transplants to immunodeficient mice. The main class of LICs is presented by immature precursors with $\mathrm{CD} 34^{+} \mathrm{CD} 38^{-}$immunophenotype which, in turn, are capable of selective expression of BAALC gene. The second class of LICs is presented by relatively mature precursors with more differentiated immunophenotypes. According to indirect findings, they are able of WT1 gene expression, along with blast cells. Since both $B A A L C$ and WT1 mRNAs may be quantitatively evaluated by means of standardized quantitative polymerase reaction in real time (qRT-PCR), this approach may be effective for specifying the mechanisms of relapses and resistance to therapy in AML patients. The aim of this work was to perform simultaneous dynamic evaluation of $B A A L C$ and $W T 1$ genes expressions along with determination of blast numbers in the tested bone marrow samples in 14 AML patients treated at our Center with Gemtuzumab ozogamicin (GO, Mylotarg), which was combined with high-dose chemotherapy (ChT), followed by allogeneic hematopoietic stem cell transplantation (allo-HSCT). Our preliminary results are as follows: a) superior 3-year overall survival (OS) in general group of patients with normal or nearly-normal karyotypes, and FLT3-mutated AML variants as compared to those with more complex karyotypes and EVI1 gene overexpression (85.7\% vs $16.7 \%$; $\mathrm{p}=0.032$ ); b) highly sensitive response of immature $B A A L C$-expressing precursors to combined ChT and GO treatment; c) hypothetical participation of some mature precursors, along with blast cells, in WT1 gene expression; d) real evidence for switching hematopoietic regulation from immature $B A A L C$-expressing precursors to more mature WT1-expressing progeny. These results suggest diagnostic utility of combined BAALC/ WT1/blast counts panel for quantitative studies and assessment of distinct precursors in AML progression and emergence of relapses.

\section{Keywords}

Acute myeloid leukemia, resistance to therapy, relapses, pathogenesis, Gemtuzumab ozogamycin, BAALC expression, WT1 expression, leukemic cell precursors, qRTPCR. 


\section{Introduction}

Over last decade, several experimental studies showed a heterogeneity of myeloid leukemia precursor cells in human acute myeloid leukemia (AML)[1-4]. This population includes, at least, immature leukemia-initiating cells (LIC) with $\mathrm{CD} 34^{+} \mathrm{CD} 38^{-}-$immune phenotype, being able for selective $B A A L C$ gene expression [5], whereas more mature LIC were attributed to acute promyelocytic leukemia (APL) origin. Biology of the latter cell population has been yet poorly studied. From some indirect data, one may suggest that these precursors, along to blast cells [6-11], may participate in WT1 gene expression $[11,12]$. One line of evidence is based on some cases of acute promyelocytic leukemia (APL), where higher level of gene WT1 expression was coupled to lower blast cell numbers in bone marrow [12]. Moreover, this conclusion is also supported by similar discrepancy between higher WT1 gene expression and lower numbers of bone marrow blasts in $30 \%$ to $40 \%$ AML patients, both before and after HSCT $[6,9,10,13,14]$. In our opinion, this phenomenon may be also explained by presence of active expression of WT1 gene by more mature precursors $[12,15]$. Confirmation of this hypothesis should extend our opportunities for evaluation of leukemic hematopoiesis on the level of leukemic precursors, using quantitative qRT-PCR $[12,14,15]$. To test this hypothesis, we performed parallel measurements of $B A A L C$ and WT1 expression levels in 14 AML patients with different cytological, cytogenetic and molecular variants of AML treated with combination of high-dose chemotherapy (ChT) and Mylotarg. Moreover, allogeneic hematopoietic stem cell transplantation (HSCT) was performed in 11 cases. It should be noticed here that our choice of Mylotarg was determined by some biological effects of this drug. Firstly, we have recently revealed unexpected response of leukemic cells to this drug, accompanied by elevation of WT1 gene expression [13]. Secondly, some data suggest a direct action of Mylotarg upon immature precursor cells with $\mathrm{CD} 34^{+} \mathrm{CD} 38^{-}-$phenotype [16]. Worth of note, more pronounced response to Mylotarg was revealed in AML with normal karyotypes and, especially, in those with FLT3 gene mutations [17]. This effect may be explained by higher expression of CD33 antigens on the surface of leukemic cells in AML with mutated FLT3 [18, 19]. On the contrary, overall survival in AML patients with WT1 gene overexpression became shorter, being in good accordance with our present findings.

Hence, the aim of our work was to study feasibility of BAALC/ WT1 molecular panel for evaluation of hematopoiesis on the level of variously differentiated leukemic progenitors in the group of treated with Mylotarg patents with various cytogenetic and molecular AML variants, using standardized qRT-PCR approach.

\section{Patients and methods}

\section{Clinical evaluation}

Our study included fourteen patients (4 pediatric, 10 adults) at the age of 3 to 67 years (median of 25.7 years) with various morphological, cytogenetic and molecular variants of AML (Table 1). All the patients were resistant to standard chemotherapy, thus using Gemtuzumab ozogamicin (GO,
Mylotarg) in subsequent treatment. One of these patients and his WT1 changes was earlier reported as a case No.22 [13]. These data were supplemented by new results concerning $B A A L C$ gene expression. The basic part of present work concerns clinical and molecular biology data obtained in 13 newly studied AML patients treated at our Center by combination of high-doses ChT, GO treatment and HSCT $(n=11)$.

\section{Laboratory studies}

Routine laboratory counts of blood and bone marrow cells were performed, along with regular testing of blood chemistry. Cytogenetic studies were carried out using standard criteria to detect chromosome aberrations. Simultaneous serial measurements of BAALC and WT1 gene expressions levels were performed with quantitative real-time polymerase chain reaction (qRT-PCR), according to earlier described technique [20]. In brief, RNA was isolated from the fresh bone marrow samples by guanidine-phenol-chloroform extraction ("Ribozol-DF" kit reagent, InterLabService, Russia), according to the manufacturer's instructions. Aliquots of extracted RNA (11 mcL) were used for reverse transcription with cDNA Synthesis Kit (LifeTechnologics, USA). The multiplex PCR of BAALC, WT1 and $A B L$ genes was performed for each cDNA sample. Reaction conditions were as follows; $10 \mu \mathrm{cL}$ of PCR reaction mixture ("Syntol", Russia), containing dNTP mix of $2.5 \mathrm{mM}$ each, $10 \times$ PCR buffer, 5 Units of Taq-DNA polymerase and $2.5 \mu \mathrm{cL}$ of $25 \mathrm{mM} \mathrm{MgCl}_{2}, 7 \mathrm{pmol}$ of each gene-specific primers, 5 pmol of Taqman probes for both $B A A L C, W T 1$ and $A B L$ genes. Cutoff value of $31 \%$ was accepted for $B A A L C$ expression. The threshold level for $W T 1$ gene was 250 copies $/ 10^{4}$ copies of $B C R / A B L 1$ gene.

Along with individual assessment of clinical response, the patients were classified in 2 groups: (1) with FLT3 mutations and normal/near-normal karyotypes, and (2) more complex chromosome aberrations and EVI1 gene overexpression.

The prognostic significance of GO treatment in common group with normal, near-normal karyotypes and FLT3-mutated AML were compared to those with complex chromosome aberrations and EVI1 gene overexpression estimated by plotting of overall survival (OS) and relapse risk curves, according to Kaplan-Meier, SPSS software version 22.0 (IBM corporation, Armonk, NY, USA) were used for statistical analysis.

\section{Results}

Basic clinical and laboratory findings in 13 newly studied AML patients treated with GO (Mylotarg) were presented in Table 1. In general, the results obtained in Mylotarg-treated group have shown that AML patients with normal or near-normal karyotypes, and mutated FLT3 variants (subgroup 1) exhibited higher 3-year OS rates, as compared to AML cases with complex karyotypes and EVI1-positivity (Fig.1). The difference in 3-year overall survival (OS) proved to be statistically significant $(85.7 \%$ vs $16.7 \%$; $<<0.032)$.

To interpret the differences observed, we would like to report in details some indicative cases with significant changes of $B A A L C$ expression. E.g., we observed a 67-year-old man with AML (M0 FAB variant) diagnosed in 2016. Interestingly, 
Table 1. Clinical and laboratory parameters of AML patients subjected to combined treatment with high-dose ChT, G0, and allo-HSCT performed in 11 cases

\begin{tabular}{|c|c|c|c|c|c|c|c|c|c|c|c|c|c|c|}
\hline \multirow{2}{*}{\multicolumn{4}{|c|}{ Patients }} & \multicolumn{10}{|c|}{ Mylotarg } & \multirow{4}{*}{$\begin{array}{l}\text { OS, } \\
\text { days }\end{array}$} \\
\hline & & & & & & Before & & & & & After & & & \\
\hline \multirow{2}{*}{ \# } & \multirow{2}{*}{$\begin{array}{l}\text { Age, } \\
\text { gen- } \\
\text { der }\end{array}$} & \multirow{2}{*}{$\begin{array}{l}\text { FAB- } \\
\text { vari- } \\
\text { ant }\end{array}$} & \multirow{2}{*}{$\begin{array}{l}\text { Karyotype } \\
\text { (Molecular Markers) }\end{array}$} & \multirow{2}{*}{ Date } & \multicolumn{4}{|c|}{ Tested parameters } & \multirow{2}{*}{ Date } & \multicolumn{4}{|c|}{ Tested parameters } & \\
\hline & & & & & $\begin{array}{l}\text { BAALC, } \\
\%\end{array}$ & $\begin{array}{l}\text { WTI, } \\
\text { copies }\end{array}$ & $\begin{array}{l}E V I I_{1} \\
\%\end{array}$ & $\begin{array}{l}\text { Blasts, } \\
\%\end{array}$ & & $\begin{array}{l}\text { BAALC, } \\
\%\end{array}$ & $\begin{array}{l}\text { WTI, } \\
\text { copy }\end{array}$ & $\begin{array}{l}\text { EVII, } \\
\%\end{array}$ & $\begin{array}{l}\text { Blasts, } \\
\%\end{array}$ & \\
\hline 1 & $22, \mathrm{f}$ & M1 & $46, X X$ & 8.11 .17 & 104 & 1265 & 0.1 & 72 & 16.01.18 & 11 & 6 & 5 & 2 & $807+$ \\
\hline 2 & $7, f$ & M2 & $46, X X$. del(5q31) & 12.10.18 & 263 & 4164 & 0.02 & 48 & 14.01.19 & 53 & 1693 & 0.1 & 52 & $700+$ \\
\hline 3 & $11, \mathrm{~m}$ & M4 & $46, X Y\{N U P m u t\}$ & 9.08 .19 & 287 & 22725 & 0.1 & 91 & 10.09 .19 & 12 & 503 & 3 & 10 & $374+$ \\
\hline 4 & $38, f$ & M2 & $\begin{array}{l}46, X X, t(6 ; 7) \\
(\mathrm{p} 21 ; \mathrm{p} 22), \\
-13,+19,+21,+\mathrm{mar} \\
\{\mathrm{FLT3dupl}\}\end{array}$ & 24.10 .17 & 0.1 & 0.1 & 0.1 & 2 & 18.11.19 & 5 & 25 & 6 & 0.6 & $1155+$ \\
\hline 5 & $19, \mathrm{~m}$ & M0 & $47, \mathrm{XY},+6\{$ FLT3dupl $\}$ & 8.11 .18 & 34 & 3165 & 0.01 & 84 & 15.03 .19 & 8 & 6 & 3 & 2 & $558+$ \\
\hline 6 & $34, \mathrm{~m}$ & M2 & 46,XY, \{FLT3dupl\} & 21.02 .19 & 247 & 1419 & 0.1 & 79 & 7.10 .19 & 9 & 33 & 3 & 0.8 & $495+$ \\
\hline 7 & $31, m$ & M0 & $\begin{array}{l}47, \mathrm{XY},+8 / 47, \mathrm{XY},+22 \\
\{\mathrm{FLT3dupl}\}\end{array}$ & 13.03. 17 & 101 & 3204 & 0 & 80 & 7.03 .19 & 34 & 3883 & 1 & 7 & $\dagger 92$ \\
\hline 8 & $43, f$ & M1 & $\begin{array}{l}\text { 46,XX,t(11; 19), } \\
\text { t(10;18),t12;17), } \\
\text { 16q+,20p+,17q-, } \\
\text { inv(3) [FLI3dupl, } \\
\text { NPMI mut\} }\end{array}$ & 30.10 .17 & 54 & 2849 & 0.1 & 92 & 21.11.17 & 17 & 1471 & 0.1 & 83 & $\dagger 116$ \\
\hline 9 & $30, \mathrm{~m}$ & Ml & $\begin{array}{l}46, X Y, t(9 ; 11)(p 22 ; q 23) \\
\{E V I 1+\}\end{array}$ & 13.03.17 & 54 & 3182 & 119 & 80 & 31.08 .17 & 0.1 & 0.1 & 0.1 & 2 & $1200+$ \\
\hline 10 & $28, f$ & M4 & $\begin{array}{l}46, X X, d e l(11(q 23) \\
\{E V I I+\}\end{array}$ & 9.01 .19 & - & 189 & 023 & 20 & 15.01.19 & 16 & 13 & 2 & 3 & $\dagger 172$ \\
\hline 11 & $20, f$ & M5 & $\begin{array}{l}\text { 46,XX,del(7)(q36), } \\
\text { t(11;19)(q23;p?) } \\
\{\mathrm{EVVIl+ \}}\end{array}$ & 19.12.18 & 26 & 1807 & 23 & 16 & 11.03 .19 & 14 & 37 & 0.008 & 5.6 & $\dagger 497$ \\
\hline 12 & $35, f$ & M5 & $\begin{array}{l}46, X X, t(1 ; 4)(35 ; q 12) \\
\{E V I 1+\}\end{array}$ & 9.01 .19 & - & 967 & 121 & 8.8 & 28.05.19 & 8 & 2139 & 0.3 & 81 & $\dagger 82$ \\
\hline 13 & $3, \mathrm{~m}$ & M7 & $\mathrm{n} / \mathrm{d}$ & 28.11.17 & 0.1 & 5166 & 0.1 & 92 & 5.02 .18 & 0.1 & 2755 & 1 & 77 & $† 435$ \\
\hline
\end{tabular}

Notes: $\dagger$, died patients; $n / d-n o t$ done. Significant parameters are shown in bold

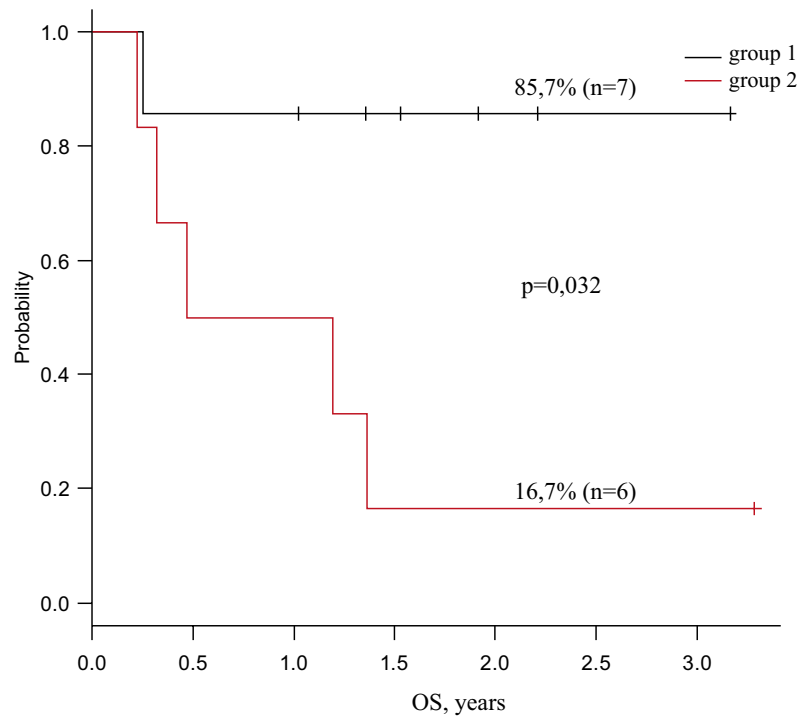

Figure 1. 3-year overall survival in AML patents with normal, near-normal karyotypes and FLT3-mutated variants (group 1) and those with more complex karyotypes and EVIl-positive leukemia (group 2) 
the cytogenetic analysis revealed karyotype with trisomy of chromosome 8 , where the BAALC gene is mapped. As shown in Fig. 2, the BAALC expression was sufficiently increased (833\%) which cannot be explained by trisomy 8 only. Moreover, the $B A A L C$ overexpression was accomplished by similar increase of WT1 gene up to 681 copies which could correlate with higher number of blasts in the tested bone marrow (59.8\%).

This ratio was sufficiently changed after Mylotarg treatment, i.e., BAALC gene expression associated with contents of common $B A A L C$-expressing precursors decreased to the threshold level (37\%). In contrast, 13-fold elevation of WT1 expression was revealed, whereas percentage of marrow blasts was only slightly increased. Hence, we may assume that, at least in this case, higher WT1 expression might be provided by some distinct precursor subpopulation, along with blast cells.

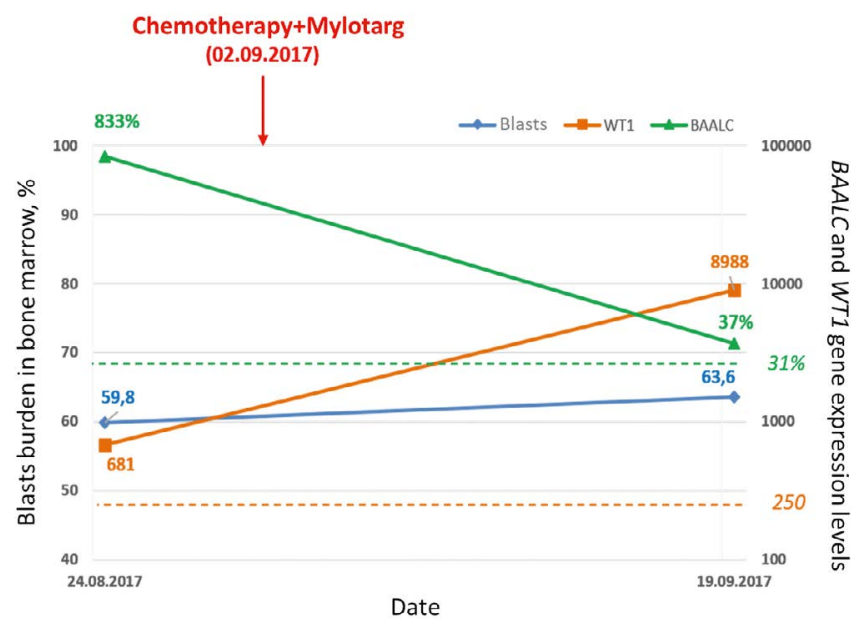

Figure 2. Relative BAALC- and WT7-expression by the bone marrow precursors in a 67-year old patient with MO AML showing opposite responses to Mylotarg therapy without significant effect upon bone marrow blast counts

Ordinate: percentage of blast cells (left); relative $B A A L C$ and $W T 1$ gene expression, $\%$ and copies, respectively.
Apart from this patient, the highest levels of BAALC gene expression (>200\%) before Mylotarg therapy were observed in patients \#2, 3 and 6 who had normal or nearly-normal karyotypes. Intermediate levels of this gene (from 100 to 199\%) were found in patients \#1 and \#7 with normal or moderately changed karyotypes. Lower levels of BAALC expression were characteristic for all other patients including three cases (\#4, 11 and 13) with sub-threshold levels of this gene expression.

As mentioned above, clinical response to GO therapy, in terms of leukemic cell counts, was not uniform. In most cases $(9 / 11)$, the level of $B A A L C$ expression was decreased, thus presuming a direct inhibitory effect of GO upon immature leukemic precursors. Some of GO-treated patients (\# 1-3) showed a simultaneous decrease of both WT1 gene and blast cell counts in the tested bone marrows.

However, such response was not revealed in AML case \#12, as shown in Table 2 .

As shown above (Fig. 1), this positive response of Mylotarg was more pronounced in patients with normal or close to normal karyotypes, as well as in 6/8 (75\%) cases with tandem duplication of FLT3 gene, except of a patient \#8 with M1 FAB-variant, in whom, along with FLT3 duplication, multiple chromosome aberrations and NPMI mutation were found (Table 3).

At diagnosis, this patient had WBC counts of $75.2 \times 10^{9} / \mathrm{L}$ and high blast numbers $(88 \%)$ in bone marrow and peripheral blood. Initial therapy included hydroxyurea $(3 \mathrm{~g})$, followed by standard $7+3$ protocol. Clinical and hematological remission with $3.8 \%$ blasts in bone marrow was established on 5.09.17. However, the blast cell number had already increased to $70 \%$ a month later. As seen from data at Table 3, these leukemic cells contained complex karyotype with 3 various translocations, 2 deletions, inv(3), internal duplication of FLT3 receptor and NPM1 gene mutation. Initially, BAALC and EVI1 expression levels were 54 and $0.1 \%$, respectively. At the same time, the level of WT1 (2849 copies) and the numbers of blast cells in bone marrow sample (92\%) were higher. Meanwhile, the initial effects of $7+3$ and FIAMx2 protocols were insufficient, since the WT1 gene expression decreased to 1471 copies only.

Table 2. Parallel serial measurements of $B A A L C, W T 1, E V I I$ gene expression and bone marrow blasts in the patient with M5 FAB-variant of AML (№12) treated by Mylotarg and HSCT

\begin{tabular}{|c|c|c|c|c|c|c|c|c|c|}
\hline \multicolumn{4}{|c|}{ Before therapy 9.01.19 } & \multirow{2}{*}{$\begin{array}{c}\text { G0, other therapy, } \\
\text { dates }\end{array}$} & \multicolumn{5}{|c|}{ After therapy/before next course } \\
\hline$B A A L C, \%$ & WTI, copies & $E V I I, \%$ & $\begin{array}{l}\text { Blasts, } \\
\text { b.m., \% }\end{array}$ & & $\begin{array}{l}\text { Sampling } \\
\text { dates }\end{array}$ & $B A A L C, \%$ & WTI, copies & $E V I I, \%$ & $\begin{array}{l}\text { Blasts, } \\
\text { b.m., \% }\end{array}$ \\
\hline- & 967 & 121 & 8.8 & $\begin{array}{c}\text { G0-FLAG } \\
28.05-9.06 .19\end{array}$ & & & & & \\
\hline \multirow{2}{*}{\multicolumn{4}{|c|}{$46, X X, t(1 ; 4)(p 35 ; q 12)$}} & $\begin{array}{c}\text { Allo-HSCT } \\
\text { non-related 18.07.19 }\end{array}$ & 7.10 .19 & 8 & 2139 & 0.3 & 81.4 \\
\hline & & & & & & \multicolumn{4}{|c|}{ †8.10.19; 0S - 82 days } \\
\hline
\end{tabular}


Table 3. Simultaneous serial measurements of BAALC, WTI and EVII expression levels, and blast percentage in bone marrow aspirates of a female patient with M2 FAB variant of AML (\#8) treated by G0 only

\begin{tabular}{|c|c|c|c|c|c|c|c|c|c|}
\hline \multicolumn{4}{|c|}{ Before therapy 30.10.17 } & \multirow{2}{*}{$\begin{array}{l}\text { G0, other therapy, } \\
\text { dates }\end{array}$} & \multicolumn{5}{|c|}{ After therapy/before next course } \\
\hline BAALC, \% & WTI, copies & $E V I I, \%$ & $\begin{array}{l}\text { Blasts, } \\
\text { b.m., \% }\end{array}$ & & $\begin{array}{l}\text { Sampling } \\
\text { dates }\end{array}$ & $B A A L C, \%$ & WTI, copies & $E V I I, \%$ & $\begin{array}{l}\text { Blasts, } \\
\text { b.m., \% }\end{array}$ \\
\hline \multirow{2}{*}{54} & \multirow{2}{*}{2849} & \multirow{2}{*}{0.1} & \multirow{2}{*}{92} & \multirow{2}{*}{$\begin{array}{l}\text { 7+3. FLAMx2 G0 } \\
31.07 .17\end{array}$} & 21.11.17 & 17 & 1471 & 0.1 & 83.4 \\
\hline & & & & & 14.12.17 & & & & 98 \\
\hline \multicolumn{5}{|c|}{$\begin{array}{c}\text { 46,XY, t(11;19),t(10;18),t(12;17), add(6q),add(20p),del(11p),del(17q),inv(3) } \\
\text { \{intern dupl. FLT3, NPM1+\} }\end{array}$} & \multicolumn{5}{|c|}{ †24.12.17; 0S-145 days. } \\
\hline
\end{tabular}

In addition, the number of blasts in bone marrow samples increased initially to $83.4 \%$, but soon reached $92 \%$. Under these conditions, HSCT procedure became impossible, despite presence of available HLA-matched related donor. Death was registered on 24.12.17., 145 days after GO therapy.
As example of positive therapeutic effect of combined therapy with Mylotarg and HSCT, we present here detailed clinical and laboratory data from 2 of 13 patients (\# 4 and \#9).

Table 4. Simultaneous serial measurements of BAALC, WTI and EVII expression levels, and blast percentage in bone marrow aspirates of a female patient with M2 FAB variant of AML (№4) in whom initial remission was achieved by high- dosage ChT (protocol FLAG) combined with double HSCT, followed by $\mathrm{GO}$ and Gilteritinib

\begin{tabular}{|c|c|c|c|c|c|c|c|c|c|}
\hline \multicolumn{4}{|c|}{ Before therapy 24.10 .17} & \multirow{2}{*}{$\begin{array}{l}\text { G0, other therapy } \\
\text { dates }\end{array}$} & \multicolumn{5}{|c|}{ After therapy/before next course } \\
\hline$B A A L C, \%$ & WTI, copies & $E V I I, \%$ & $\begin{array}{l}\text { Blasts, } \\
\text { b.m., \% }\end{array}$ & & $\begin{array}{l}\text { Sampling } \\
\text { dates }\end{array}$ & BAALC, \% & WTI, copies & $E V I I, \%$ & $\begin{array}{l}\text { Blasts, } \\
\text { b.m., \% }\end{array}$ \\
\hline \multirow{6}{*}{0.1} & \multirow{6}{*}{0.1} & \multirow{6}{*}{0.1} & \multirow{6}{*}{2.4} & FLAG & 02.2017 & & & & 95.2 \\
\hline & & & & Allo-HSCT, unrelated 8.11.17 & 12.02 .18 & 0.1 & 0.1 & 0.1 & 2 \\
\hline & & & & & 10.12 .18 & 2 & 1 & 0.002 & 0.6 \\
\hline & & & & $\begin{array}{l}\text { Haplo-HSCT related } \\
14.06 .19\end{array}$ & 20.03.19 & 7 & 156 & 2 & 3.6 \\
\hline & & & & Anti-relapse therapy & 29.08 .19 & 72 & 2 & 1 & 19.6 \\
\hline & & & & G0-FLAG, IDL 4.10.19 & 18.11.19 & 5 & 25 & 6 & 0.6 \\
\hline \multirow{3}{*}{\multicolumn{4}{|c|}{$\begin{array}{c}46, X X, t(6 ; 7)(p 21 ; p 22),-13, \\
+19,+21,+\operatorname{mar}[6] / 46, X X[9]\{F L T 3 / I T D\}\end{array}$}} & Gilteritinib & 16.12 .19 & 2 & 16 & 2 & 2.8 \\
\hline & & & & & 20.01 .20 & 6 & 30 & 2 & 0.5 \\
\hline & & & & & & & \multicolumn{3}{|c|}{ 0S -1155 days } \\
\hline
\end{tabular}

On the other hand, the expected negative reactions of leukemic hematopoiesis to GO therapy were noticed in 3 of 4 patients with EVI1-positive variants of AML (\#10-12). The only exclusion was a young patient (\#9) with more prognostically favorable for this group translocation $\mathrm{t}(9 ; 11)(\mathrm{p} 22 ; \mathrm{q} 23)$. At diagnosis, he had no increased numbers of blast cells in peripheral blood, whereas it reached $77.5 \%$ in bone marrow.

Cytogenetic study revealed a standard translocation $\mathrm{t}(9 ; 11)$ (p22;q23), which involves KMT2A gene and is, generally, associated with intermediate risk (Table 5). After a course of standard chemotherapy $(7+3$ protocol), her WBC decreased to $3 \times 10^{9} / \mathrm{L}$ with $43 \%$ of blast cells. Further treatment included two more intensive chemotherapy courses (FLAM protocol). Consequently, clinical, cytogenetic and molecular remissions were established. At this time (14.03.15), HSCT was performed, which was soon complicated by unexpected elevation of $W T 1$ and $M L L / A F 9$ expression, although essential increase of bone marrow blasts number (to $81.4 \%$ ) appeared much later (31.08.17). Therefore, GO was administered for further treatment. The patient is alive now, and her survival following GO and haplo-HSCT has reached 1200 days.

\section{Discussion}

Our preliminary study contains data which support earlier data on better response to Mylotarg therapy patients with 
Table 5. Simultaneous serial measurements of BAALC, WTI and EVII expression levels, and blast percentage in bone marrow aspirates of a female patient with M2 FAB variant of AML (№9) treated by Mylotarg and HSCT

\begin{tabular}{|c|c|c|c|c|c|c|c|c|c|}
\hline \multicolumn{4}{|c|}{ Before therapy 13.03.17 } & \multirow{2}{*}{$\begin{array}{c}\text { G0, other therapy, } \\
\text { dates }\end{array}$} & \multicolumn{5}{|c|}{ After therapy/before next course } \\
\hline BAALC, \% & WTI, copies & $E V I I, \%$ & $\begin{array}{l}\text { Blasts, } \\
\text { b.m., \% }\end{array}$ & & $\begin{array}{l}\text { Sampling } \\
\text { dates }\end{array}$ & $B A A L C, \%$ & WTI, copies & EVII,\% & $\begin{array}{l}\text { Blasts, } \\
\text { b.m., \% }\end{array}$ \\
\hline \multirow{6}{*}{54} & \multirow{6}{*}{3182} & \multirow{6}{*}{119} & \multirow{6}{*}{80} & 7+3. FLAMx2 G0 31.07.17 & 02.2017 & & & & 95.2 \\
\hline & & & & $\begin{array}{l}\text { Haplo-related HSCT } \\
8.09 .17\end{array}$ & 12.02 .18 & 0.1 & 0.1 & 0.1 & 2 \\
\hline & & & & & 10.12 .18 & 2 & 1 & 0.0002 & 0.6 \\
\hline & & & & & 20.03.19 & 7 & 156 & 2 & 3.6 \\
\hline & & & & Anti-relapse therapy & 29.08 .19 & 72 & 2 & 1 & 19.6 \\
\hline & & & & & 18.11.19 & 5 & 25 & 6 & 0.6 \\
\hline \multirow{3}{*}{\multicolumn{4}{|c|}{$46, X X, t(9 ; 11)(p 22 ; q 23)\{E V I 1+\}$}} & & 16.12 .19 & 2 & 16 & 2 & 2.8 \\
\hline & & & & & 20.01 .20 & 6 & 30 & 2 & 0.5 \\
\hline & & & & & & & OS 1200 day & & \\
\hline
\end{tabular}

normal and favorable cytogenetic variants, as well as higher sensitivity to Mylotarg treatment in AML with FLT3 mutations [17]. Vice versa, the results of this therapy are significantly worse in AML with complex karyotypes and EVI1 gene overexpression which may be mutually combined. A significant decrease of $B A A L C$ gene expression in most GO-treated AML patients is in accordance with earlier conclusions about inhibitory effect of Mylotarg upon immature $B A A L C$-expressing precursors [16].

On the other hand, the data presented here suggest a possible dichotomy for BAALC and WT1 gene expression, due to their divergent changes, thus allowing an existence of hypothetical regulatory switch in leukemic hematopoiesis from earlier $B A A L C$-expressing precursors to their more mature WT1-expressing progeny.

In general, the molecular diagnostic panel suggested by us, based on simultaneous quantitative measurements of BAALC- and WT1- expressing mRNA using standard qRT-PCR, allows to obtain useful fundamental and applied data which might be available for further search in subtle molecular mechanisms of AML resistance to therapy, as well as emerging relapses at the precursor cell level in different cytogenetic and molecular AML variants.

\section{Conclusion}

The study of leukemic hematopoiesis in AML patients with different cytogenetic and molecular variants treated with GO in combination with high doses ChT and HSCT, using simultaneous quantitative monitoring of $B A A L C$ - and WT1-expression by leukemic precursors, provides novel tools for deeper studying the precise mechanisms of AML resistance to therapy and relapse emergence at the level of earlier precursors, thus being important in fundamental and applied aspects.

\section{Acknowledgements}

The authors would like to acknowledge the assistance of Professor A. B. Chukhlovin in the preparation of this paper.

\section{Conflict of interest}

No conflict of interest are reported.

\section{References}

1. Lapidot T, Sirard C, Vorm J, Murdoch B, Hoang T, Caceres-Cortes J, Minden M, Paterson B, Caligiuri MA, Dick JE. A cell initiating human acute myeloid leukaemia after transplantation into SCID mice. Nature 1994; 367(6464): 645648. doi: $10.1038 / 367645 \mathrm{a} 0$.

2. Taussig DC, Vargaftig J, Miraki-Moud F, Griessinger E, Sharrock K, Luke T, Lillington D, Oakervee H, Cavenagh J, Agrawal SG et al. Leukemia-initiating cells from some acute myeloid leukemia patients with mutated nucleophosmin reside in the CD34- fraction. Blood 2010; 115 (10): 1976-1984. doi: 10.1182/blood-2009-02-206565.

3. Patel S, Zhang Y, Cassinat B, Zassadowski F, Ferré N, Cuccuini W, Cayuela JM, Fenaux P, Bonnet D, Chomienne C, Louache F. Successful xenografts of AML3 samples in immunodeficient NOD/shi-SCID IL2R $\gamma^{-} /{ }^{-}$mice. Leukemia 2012; 26(11):2432-2435. doi: 10.1038/leu.2012.154.

4. Walter R, Appelbaum F, Estey E, Bernstein I. Acute myeloid leukemia stem cells and CD33-targeted immunotherapy. Blood 2012; 119: 6198-6208. doi: 10.1182/ blood-2011-11-325050.

5. Morita K, Masamoto Y, Kataoka K, Koya J, Kagoya Y, Yashiroda H, Sato T, Murata S, Kurokawa M. BAALC potentiates oncogenic ERK pathway through interactions with MEKK1 and KLF4. Leukemia 2015; 29(11): 2248-2256. doi: $\underline{10.1038 / \text { leu.2015.137. }}$. 
6. Cilloni D, Gottardi A, De Micheli D, Serra A, Volpe G, Messa F, Rege-Cambrin G, Guerrasio A, Divona M, Coco FL, Saglio G. Quantitative assessment of WT1 expression by real time quantitative PCR may be a useful tool for monitoring minimal residual disease in acute leukemia patients. Leukemia 2002; 16: 2115-2121. doi: 10.1038/sj.leu.2402675.

7. Cilloni D, Saglio G.WT1 as a universal marker for minimal residual disease detection and quantification in myeloid leukemias and in myelodysplastic syndrome. Acta Hematol 2004; 112: 79-84. doi: 10.1159/000077562.

8. Cilloni D, Renneville A, Hermitte F, Hills RK, Daly S, Jovanovic JV, Gottardi E, Fava M, Schnittger S, Weiss T et al. Real-time quantitative polymerase chain reaction detection of minimal residual disease by standardized WT1 assay to enhance risk stratification in acute myeloid leukemia: a European LeukemiaNet study. J Clin Oncol 2009; 27 (31): 5195-5201. doi: 10.1200/JCO.2009.22.4865.

9. Candoni A, Toffoletti E, Gallina R, Simeone E, Chiozzotto M, Volpetti S, Fanin R. Monitoring of minimal residual disease by quantitative WT1 gene expression following reduced intensity conditioning allogeneic stem cell transplantation in acute myeloid leukemia. Clin Transplant 2011; 25(2): 308-316. doi: 10.1111/j.1399-0012.2010.01251.x.

10. Gudozhnikova YaV, Mamaev NN, Barkhatov IM, Katerina VA, Gindina TL, Shakirova AI, Bondarenko SN, Slesarchuk OA, Darskaya EI, Paina OV, Zubarovskaya LS, Afanasyev BV. Results of molecular monitoring in posttransplant period by means of series investigation of WT1 gene expression in patients with acute myeloid leukemia. Clinical Oncohematology 2018; 11(3): 241-251. doi: 10.21320/25002139-2018-11-3-241-251 (In Russian).

11. Goel H, Rahul E, Gupta AK, Meena JP, Chopra A, Ranjan A, Hussain S, Rath GK, Tanwar P. Molecular update on biology of Wilms Tumor 1 gene and its applications in acute myeloid leukemia. Am J Blood Res 2020; 10(5): 151-160. PMCID: PMC7675129. PMID: 33224559.

12. Mamaev NN, Shakirova AI, Barkhatov IM, et al. New opportunities for assay of leukemia initiating cells (LICs) participating in post-transplant relapse development in the patients with acute myeloid leukemia. $3^{\text {rd }}$ Annual $\mathrm{IACH}$ Meeting, 1-3 October, 2020, Paris, report \#12.

13. Mamaev NN, Gudozhnikova YaV, Gindina TL, Barkhatov IM, Shakirova AI, Katerina VA, Gubina MV, Nikolaeva ES, Semenova EV, Paina OV et al. Efficacy of Chemotherapy in Acute Leukemia Patients Resistant to Previous Standard Treatment According to the Series Measurement of WT1 Gene Expression. Clinical Oncohematology 2018; 11 (1): 78-88. doi: 10.21320/2500-2139-2018-11-1-78-88 (In Russian).

14. Mamaev NN, Shakirova AI, Gudozhnikova YaV, Barkhatov IM, Gindina TL, Paina OV, Zubarovskaya LS, Afanasyev BV. Crucial role of BAALC-expressing progenitor cells in emergence and development of post-transplantation relapses in patients with acute myeloid leukemia. Clinical Oncohematology 2020; 13(1):75-88. doi: 10.21320/2500-2139-202013-1-75-88 (In Russian).
15. Mamaev NN, Shakirova AI, Barkhatov IM, Gudozhnikova YV, Gindina TL, Kanunnikov MM, Kravtsova VM, Rakhmanova ZZ, Paina OV, Zubarovskaya LS. Crucial role of BAALC-expressing leukemic precursors in origin and development of posttransplant relapses in patients with acute myeloid leukemias. Int J Hematol 2020; 8(6): 127-131. doi: 10.15406/htij.2020.08.00240.

16. Jawad M, Yu N, Seedhouse C, Tandon K, Russell NH, Pallis M. Targeting of CD34 ${ }^{+} \mathrm{CD} 38^{-}$cells using Gemtuzumab ozogamicin (Mylotarg) in combination with tipifarnib (Zarnestra) in acute Myeloid Leukaemia. BMC Cancer 2012; 12(1): 431. doi:10.1186/1471-2407-12-431.

17. Jawad M, Seedhouse C, Mony U. Grundy M, Russell NH, Pallis M. Analysis of factors that affect in vitro chemosensitivity of leukemic stem and progenitor cells to gemtuzumab ozogomicin (Mylotarg) in acute myeloid leukemia. Leukemia 2010; 24(1):74-80. doi: 10.1038/leu.2009.199.

18. Ehninger A, Kramer M, Röllig C, Thiede C, Bornhäuser $M$, von Bonin $M$, Wermke $M$, Feldmann A, Bachmann M, Ehninger G, Oelschlägel U. Distribution and levels of cell surface expression of CD33 and CD123 in acute myeloid leukemia. Blood Cancer J 2014; 4, e218. doi: 10.1038/ bcj. 2014.39 .

19. Olombel G, Guérin E, Guy J, Perrot JY, Dumezy F, de Labarthe A, Bastie JN, Legrand O, Raffoux E, Plesa A et al. The level of blast CD33 expression positively impacts the effect of gemtuzumab ozogamicin patients with acute myeloid leukemia. Blood 2016; 127(17): 2157-2160. doi: 10.1182/ blood-2016-01-689976.

20. Shakirova A, Barkhatov I, Churkina A, Moiseev IS, Gindina TL, Bondarenko SN, Afanasyev BV. Prognostic significance of $B A A L C$ overexpression in patients with $A M L$ during the posttransplant period. Cell Ther Transplant 2018; 7(2):54-63. doi: 10.18620/ctt-1866-8836-2018-7-2-64-69. 


\section{Количественное изучение BAALC- и WT7-экспрессирующих клеток-предшественниц у больных с различными цитогенетическими и молекулярными вариантами ОМЛ, леченных гемтузумаб озогамицином и трансплантацией гемопоэтических стволовых клеток}

Николай Н. Мамаев, Алена И. Шакирова, Татьяна Л. Гиндина, Сергей Н. Бондаренко, Белла И. Аюбова, Ильдар М. Бархатов, Яна В. Гудожникова, Валентина М. Кравцова, Михаил М. Канунников, Олеся В. Паина, Жемал Ж. Рахманова, Татьяна Ю. Грачева, Людмила С. Зубаровская

НИИ детской онкологии, гематологии и трансплантологии им. Р. М. Горбачевой, Первый Санкт-Петербургский государственный медицинский университет им. акад. И. П. Павлова, Санкт-Петербург, Россия

\section{Резюме}

Имеются данные о том, что рецидивы острого миелобластного лейкоза (ОМЛ) тесно связаны с гетерогенностью популяции лейкозных предшественников. Можно выделить, по меньшей мере, два класса лейкоз-инициирующих клеток (ЛИК), исходя из недавних экспериментальных работ по трансплантации гемопоэтических стволовых клеток (ТГСК) иммунодефицитным мышам. Основные классы ЛИК представлены незрелыми предшественниками с иммунным фенотипом $\mathrm{CD} 34^{+} \mathrm{CD} 38^{-}$, которые, в свою очередь, способны к избирательной экспрессии гена BAALC. Другой класс ЛИК состоит из относительно зрелых предшественников с более дифференцированными фенотипами. Согласно косвенным результатам, они, наряду с бластными формами, способны к экспрессии гена WT1. Поскольку можно количественно оценить содержание мРНК BAALC и WT1 посредством стандартизированной real-time-ПЦР, то этот подход может быть эффективным для уточнения механизмов рецидивов и резистентности к терапии ОМЛ. Целью данной работы была одновременная динамическая оценка экспрессии генов BAALC и WT1, наряду с определением числа бластных форм в исследуемых образцах костного мозга у 14 пациентов с ОМЛ, леченных в нашем центре Гемтузумаб-озогамицином (ГО, Милотарг), который комбинировали с высокодозной терапией (ВДХТ) и аллогенной ТГСК. Наши предварительные результаты показали следующее: а) более высокую общую 3-летнюю выживаемость в группе пациентов ОМЛ с нормальным кариотипом или малыми нарушениями кариотипа и мутациями гена FLT3, по сравнению с больными с более сложными кариотипами и гиперэкспрессией гена EVI1 (85,7\% против $16,7 \%$; $=0,032)$; б) выраженный клинический ответ незрелых $B A A L C$-экспрессирующих предшественников на комбинированную ВДХТ и терапию ГО; в) возможное участие некоторых более зрелых предшественников в экспрессии гена WT1, наряду с бластными формами; г) реальное доказательство переключения гемопоэтической регуляции с незрелых $B A A L C$-экспрессирующих предшественников на более зрелые WT1-экспрессирующие клетки. Эти результаты указывают на диагностическую ценность комбинированной панели из экспрессии $B A A L C, W T 1$ и содержания бластных форм для количественных исследований и определения различных классов клеток-предшественников в прогрессии ОМЛ и возникновении рецидивов.

\section{Ключевые слова}

Острый миелобластный лейкоз, резистентность к терапии, рецидивы, патогенез, Гемтузумаб озогамицин, экспрессия $B A A L C$, экспрессия $W T 1$, прекурсоры лейкозных клеток, РТ-ПЦР. 